\title{
スクラムジェットエンジンモデル燃焼器内における
}

液体正アルカン燃料の燃焼特性*1

\section{Combustion Characteristics of Liquid Normal Alkane Fuels in a Model Combustor of Supersonic Combustion Ramjet Engine}

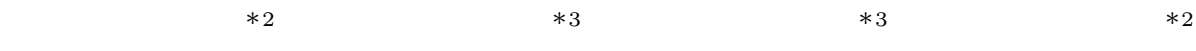 \\ Osamu Imamura, Yuta Ishikawa, Shunsuke Suzuki, Koshiro Fukumoto, \\ 西田 俊 介 $^{* 2} \cdot$ 氏 家 康 成 ${ }^{* 3} \cdot$ 津 江 光 洋*2 \\ Shunsuke Nishida, Yasushige UJIIE and Mitsuhiro Tsue
}

Key Words : Combustion, Scramjet Engine, Supersonic Combustion, Normal Alkane, Chemical and Physical Property

\begin{abstract}
Effect of kinds of one-component $n$-alkane liquid fuels on combustion characteristics was investigated experimentally using a model combustor of scramjet engine. The inlet condition of a model combustor is 2.0 of Mach number, up to $2400 \mathrm{~K}$ of total temperature, and $0.38 \mathrm{MPa}$ of total pressure. Five kinds of $n$-alkane are tested, of which carbon numbers are $7,8,10,13$, and 16 . They are more chemically active and less volatile with an increase of alkane carbon number. Fuels are injected to the combustor in the upstream of cavity with barbotage nitrogen gas and self-ignition performance was investigated. The result shows that self-ignition occurs with less equivalence ratio when alkane carbon number is smaller. This indicates that physical characteristic of fuel, namely volatile of fuel, is dominant for self-ignition behavior. Effect on flame-holding performance is also examined with adding pilot hydrogen and combustion is kept after cutting off pilot hydrogen with the least equivalence ratio where alkane carbon number is from 8 to 10 . These points are discussed qualitatively from the conflict effect of chemical and physical properties on alkane carbon number.
\end{abstract}

\section{1.は じめに}

極超音速まで加速可能な推進機関の燃料としては, 機体 を冷却する必要性や光の燃焼特性の良さから液体水素の利 用か想定されている.しかしながら液体水素は体積エネル ギ密度が小く巨大な燃料タンクが必要であること，また 将来の燃料価格の予想が困難なことなどから , システムと して成立させるためには，技術的，社会的課題が残されて いるのも事実である. 他方で航空用燃料として用いられて いる液体炭化水素燃料は, 体積エネルギ密度が大きくタン クが過剩に大きくならない上, 現在広く使われていること から安全性, 信頼性や取り扱いの容易さに利点がある . 液 体炭化水素燃料の極超音速推進機関への適応を考えるにあ たっては, 水素に対して劣っている燃焼特性や冷却性能が 問題となる。

極超音速推進機関としてスクラムジェットエンジンが考 えられているが, 以上のような理由から燃料としては水素 を対象とした研究が非常に多い．他方で炭化水素燃料を対 象とした研究も少なからず行われており, 液体の炭化水素 燃料であるジェット燃料を対象とした研究 ${ }^{1 \sim 5)}$ も見受けられ

\footnotetext{
*1 (C) 2010 日本航空宇宙学会

平成 21 年 8 月 22 日原稿受付

*2 東京大学大学院工学系研究科

*3 日本大学生産工学部
}

る . これらの研究は主に燃焼特性の改善と冷却性能の問題 に対するものである . 燃焼特性の改善 ${ }^{124)}$ については ,キャ ビティなど燃焼器の形状を工夫するもの，パイロット水素 を用いて点火を促進するもの，液体燃料を気体とともに噴 射して微粒化，混合の改善を図るものなどである．また冷 却性能については炭化水素の吸熱熱分解を冷却性能に含む 検討か潵見され，熱分解後の炭化水素を燃料とした燃焼試 験5)なども行われている.このように液体の炭化水素燃料 をスクラムジェットエンジンに適用する研究は幅広く行わ れているが, 多くの研究で対象とされているジェット燃料 は複数の炭化水素の混合物であり，また产の組成には樣々 な規格が存在する. 兴のため異なる研究者の間での結果を 比較することに障害が起こることが予想される他，多成分 の実燃料を数種類の単成分の燃料の混合物として単純化す るサロゲート燃料の提案についても, 各研究者で異なるこ とが考えられる. また燃焼器内の圧力・温度によって現象 に対する支配的な成分が異なる可能性もあり，現象の理解， 考察を困難にするものと思われる .

以上のような背景から，本報は単成分の炭化水素燃料を 用いてスクラムジェットエンジンのモデル燃焼器における 燃焼試験を行い，光れらの燃焼特性に関する基礎的な知見 の取得を目的としたものである. 単成分の燃焼特性が明ら かとなることで, 弚の混合物であるジェット燃料の燃焼特 性の議論やサロゲート燃料の提案に対する助けとなると思 
われる . ジェット燃料に多く含まれる直鎖アルカンについ て , 炭素数が 7 から 16 までの 5 種類の燃料を用いて試験を 行い, 燃料ごとの自発点火特性，保炎特性を比較した．以 下では，燃料種が燃焼特性に及ぼす影響に関する実験的な 知見と，光れに対する定性的な考察について報告する．

\section{2. 実験設備および実験条件}

2.1 試験燃料 本報において実験に使用した燃料は単 一成分の直鎖アルカン炭化水素で，正へプタン $\left(n-\mathrm{C}_{7} \mathrm{H}_{16}\right)$ ， 正オクタン $\left(n-\mathrm{C}_{8} \mathrm{H}_{18}\right)$, 正デカン $\left(n-\mathrm{C}_{10} \mathrm{H}_{22}\right)$, 正トリデ カン $\left(n-\mathrm{C}_{13} \mathrm{H}_{28}\right)$, 正へキサデカン $\left(n-\mathrm{C}_{16} \mathrm{H}_{34}\right)$ の計 5 種で ある. 以下では主に各燃料における炭素数 (アルカン炭素 数) を用いて，弚の燃料を示すこととする．第 1 表にこれ ら炭化水素燃料の主な物性值を示す. 表中の沸点のように， 一般的に直鎖アルカンの物性值はアルカン炭素数の順とな る.他方，表中には示されていないが，比熱や低位発熱量， 量論混合比における空燃比の值などはアルカン炭素数によ らず，ほぼ一定の値となる．化学的な性質については, 後 述の式 (4) を用いて評価するが, アルカン炭素数の上昇と ともに，点火遅れ時間が短くなる．

2.2 実験設備 燃焼実験は東京大学における超音速風洞 を用いて行われた . 超音速風洞の概要を第 1 図に示す. 本風 洞は吹き出し式の超音速風洞であり, 十分な気流総温を得る ために水素希薄燃焼式の加熱器をノズル上流に有している のか特徵である . 高圧タンクに貯められた空気は, 調圧弁 , 急開弁を介して加熱器および試験部に導入される . 加熱器に おいては, 水素の噴射量を調整することて総温を変化させる ことが可能であり, また水素の燃焼によって気流の酸素濃度 か変化しないよう気流に酸素を噴射して, 酸素濃度 $21 \% \mathrm{vol}$ となるよう調整している. 希薄燃焼を経て高温となった空 気は超音速ノズルを介してモデル燃焼器に導かれる . ノズ ルの設計マッハ数は 2.0 であり, 出口は $30 \mathrm{~mm} \times 36 \mathrm{~mm}$ の 矩形となっている. 試験気流は燃焼器を通過後, 消音塔を経 て大気中に放出される。よどみ点状態 (超音速ノズル直前) における総圧はおよ艺 $0.38 \mathrm{MPa} て ゙ あ り ，$ 総温は $1800 \mathrm{~K}$ か ら $2400 \mathrm{~K}$ の間で変化させた . 試験気流には水素の希薄燃 焼に伴って，約 $25 \% \mathrm{vol}$ の水蒸気が含まれており，よどみ 点の組成, 温度から求まる比熱比はおよ光 1.3 である. 過 去6) に指摘されているように，モデル燃焼器に流入する水 蒸気や化学活性種が燃焼特性に影響を及ぼすことが予想さ れるため，本報においては燃焼限界产のものの定量的な値 よりも，燃料の差異が燃焼特性に及ぼす影響について調べ ることを主眼としている．

2.3 モデル燃焼器 スクラムジェットエンジンのモデル 燃焼器の概略を第 2 図に示す . 本報においてはすべての試験
において同一の燃焼器を用いている . 燃焼器は砲金製で長 さが $400 \mathrm{~mm}$, 入り口において高さが $36 \mathrm{~mm}$, 幅が $30 \mathrm{~mm}$ の矩形断面を有し，風洞ノズルに直結されている．なお燃 焼器の冷却はしていない，燃焼器入口より $50 \mathrm{~mm}$ 下流か らおよそ $80 \mathrm{~mm}$ にわたり, キャビティが燃焼器下壁に設け てある . キャビティは横幅が燃焼器内幅と同じであり, 深 さが $12 \mathrm{~mm}$, 最深部の長さが $60 \mathrm{~mm}$, 下流には $30^{\circ}$ の傾 斜か設(てある . 文献 4), 7) から，このようなキャビティ 形状は閉キャビティとして作用し，キャビティ内部に燃料 を含む領域が生成されるものと予測される. キャビティ出 口より下流においては燃焼器下壁に 2 度の拡大角が設けて ある . 燃焼器の上壁には, 中心軸上に直径 $1 \mathrm{~mm}$ の静圧孔 が流れ方向に 23 個設けられている. 静圧孔は各々圧力導 管を介して圧力変換器に繋がっており, これらの圧力值は $500 \mathrm{~Hz}$ にてサンプリングされる . なおキャビティの入口を 原点として $x$ 軸を流れ方向が正となるように定義する .

燃料の噴射は, キャビティ入口から $18 \mathrm{~mm}$ 上流の下壁中 心軸上に設けた直径 $4 \mathrm{~mm}$ の燃料噴射孔から，気流に垂直 に噴射している．本報では液体燃料を用いており，微粒化 の促進と貫通高さを保持するため, 燃料をキャリアガスと 一緒に噴射した．本報で用いたキャリア噴射の機構は気流

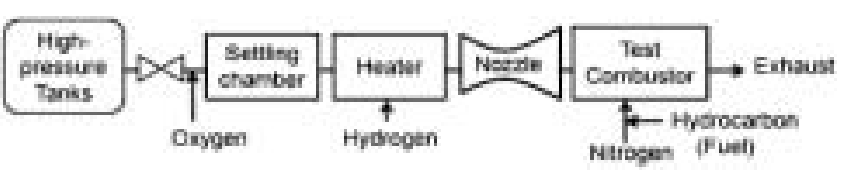

第 1 図 実験設備の概要
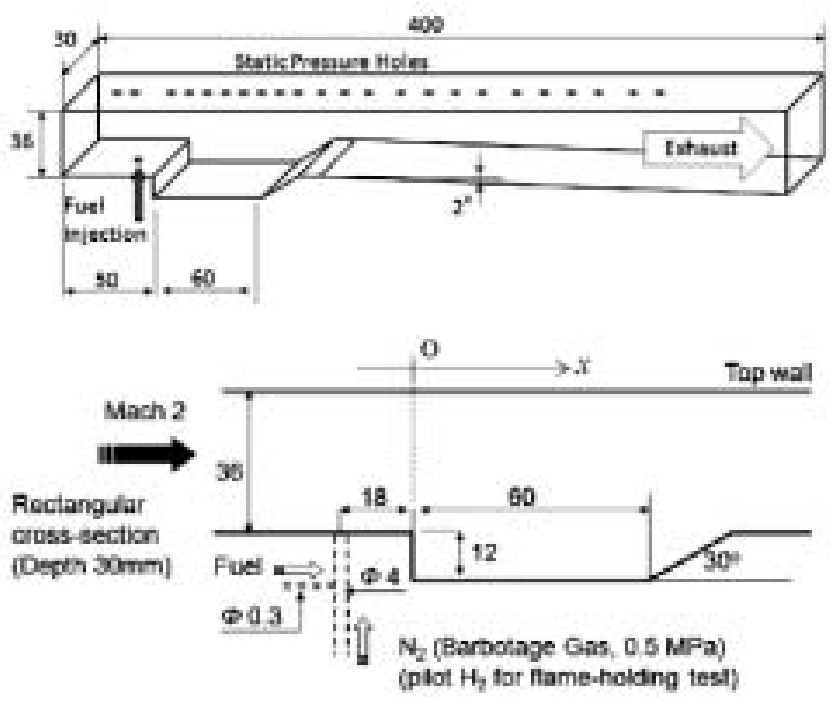

第 2 図 モデル燃焼器の概略 (上) および噴射孔近傍の模式図 (下)

第 1 表 試験した燃料の物性値

\begin{tabular}{lcccccl}
\hline Alkane carbon number & 7 & 8 & 10 & 13 & 16 & Comment \\
\hline Formula & $\mathrm{C}_{7} \mathrm{H}_{16}$ & $\mathrm{C}_{8} \mathrm{H}_{18}$ & $\mathrm{C}_{10} \mathrm{H}_{22}$ & $\mathrm{C}_{13} \mathrm{H}_{28}$ & $\mathrm{C}_{16} \mathrm{H}_{34}$ & \\
Molar weight & 100.2 & 114.2 & 142.3 & 184.4 & 226.4 & unit: g/mol \\
Boiling point & 371.6 & 398.8 & 447.3 & 508.6 & 559.9 & unit: $\mathrm{K}$, at $1 \mathrm{~atm}$ \\
Specific gravity & 0.6882 & 0.7068 & 0.7342 & 0.7601 & 0.7773 & at $15.5^{\circ} \mathrm{C}$ \\
\hline
\end{tabular}


に垂直なキャリアガスの流路に対して横方から液体燃料を 噴射して, 燃料一キャリアガスの二相流として燃焼器内に噴 射するものである ${ }^{1)}$. キャリアガスとしては室素を用いてお り，キャリアガスの噴射圧は $0.5 \mathrm{MPa}$ で一定とした . 液体 燃料は燃料容器から背圧 $0.5 \sim 10 \mathrm{MPa}$ の室素ガスによって 押し出すことによって噴射した . 液体燃料を押し出すガス の背圧を変化させることで燃料流量が変化させることがで きる、燃料配管中の流量計によって燃料流量を計測し，当 量比を算出した . 燃料噴射の開始，停止はストップバルブ の開閉操作で行っている.

2.4 実験方法 実験の方法であるが，まず急開弁を開 いて通風を開始した後に加熱器を起動し, 風洞を始動させ る. 通風開始後, およ光 1 秒後から 2.5 秒後にかけて燃料 を気流中に噴射して，壁面圧力の変化を計測した．なお保 炎試験においては燃料噴射の初期にパイロット水素を合わ せて噴射している. 1 回の試験の通風時間は, 装置の熱的 負荷の問題から，燃焼終了後の燃料配管や加熱器用水素配 管のパージを含めて 6 秒以内としている . また実験間隔も 燃燒器が室温に戻るまで十分な時間をとって行った .

\section{3. 実験結果および考察}

3.1 燃焼室圧力の時間履歴 第 3 図に保炎試験におけ るステップから下流 $30 \mathrm{~mm}$ の場所の圧力の時間履歴を示 す . 通風開始後, 燃焼室内の壁面圧力は大気圧から気流の 静圧になるように変化する. 通風開始後およ光 0.9 秒後に パイロット水素と主燃料 (この場合は正デカン) が気流内 に投入され, 自発点火による燃焼器内の圧力上昇がキャビ ティ対面の壁面圧力の上昇として捉えられている .この後 およ光 1.5 秒後からパイロット水素の添加を止め, 主燃料の みの噴射としている.壁面圧力は幾分低下しているが , 燃 料の噴射を行っていない場合に比して圧力上昇が観察され ており, 失火せず燃焼が継続されている樣子がわかる . 自 発点火試験はパイロット水素の添加がないことを除いて同 樣である .

以上の現象を燃焼器内の流れ方向の圧力分布として示し たものが第 4 図である.図には, 主流のみの場合 , キャリア 窒素のみを噴射した場合, パイロット水素と主燃料をキャ リア窒素と噴射した場合, 主燃料のみをキャリア窒素と噴 射した場合の 4 つの場合について示してあり，燃料の噴射， 燃焼によって特にキャビティ付近で顕著な圧力上昇か確認で きる.キャリア窒素の流量は $14 \mathrm{~g} / \mathrm{s}$ 程度であり主流の流量 $(2000 \mathrm{~K}$ で $189 \mathrm{~g} / \mathrm{s})$ に比して小さく，第 4 図に示されるよ うにキャリア窒素の噴射により圧力上昇は認められるもの の, 燃焼に起因する圧力上昇に比べて十分に小さい . 図に おいて $x=-110 \mathrm{~mm}$ はノズル出口に対応しており , パイ ロット水素と主燃料をともに噴射した場合においては，ノ ズル内にまで圧力上昇が遡っていることがわかる．この場 合には圧力上昇の樣子から気流は亜音速となっているもの と思われる . 以下の結果においては, キャビティ付近での 圧力上昇か認められたときに主燃料が燃焼していると判断 している.なお一次元解析から求まるキャリア窒素と燃料

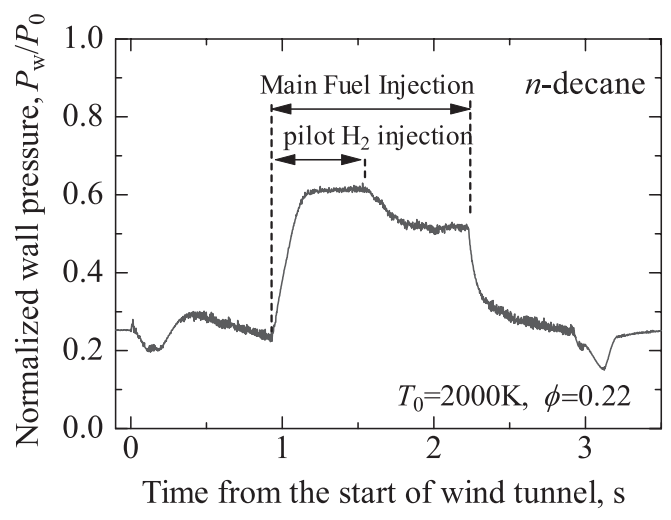

第 3 図計測された壁面圧力の時間履歴 (ステップ下流 $30 \mathrm{~mm} に$ にお けるステップの対面の壁面圧力)

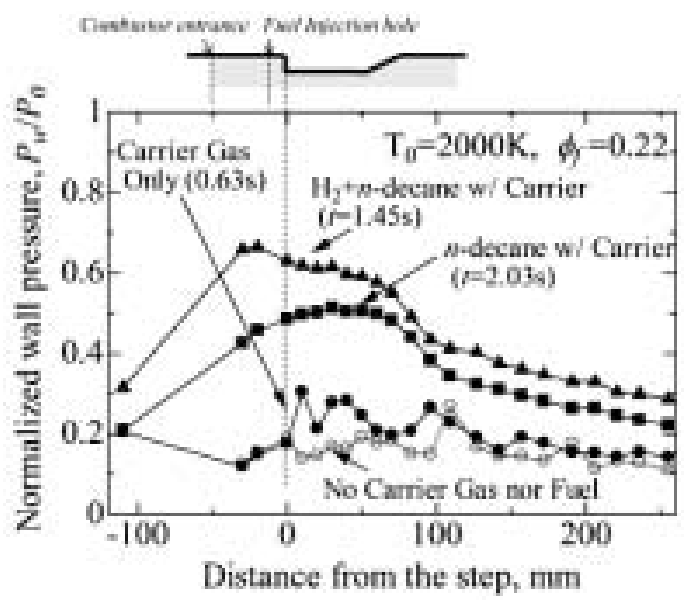

第 4 図＼cjkstart計測された壁面圧力の空間分布

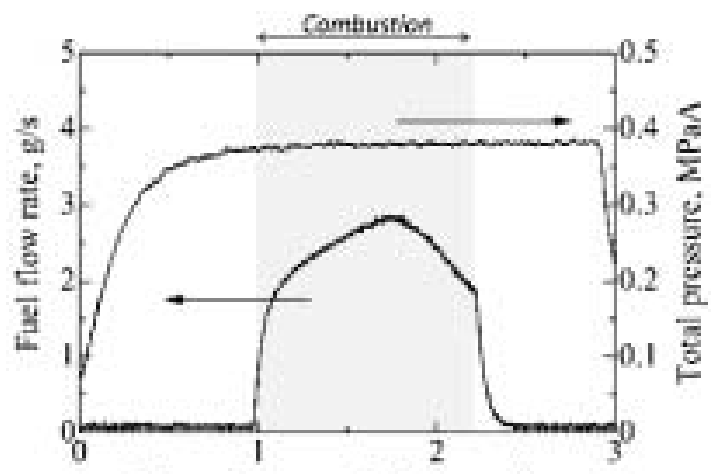

Time after start of wind tunnel. s

第 5 図 主流総圧と燃料流量の時間履歴

噴射による燃焼器のチョーク当量比は，0.33〜0.35 程度で あり,およ光これらの当量比より大きな主燃料当量比にお いては熱閉塞が観察された . 以下では熱閉塞が起こってい ない場合についての実験結果を示す．

第 5 図には主流総圧と燃料流量の時間履歴を示す .この 図に示されるように主流総圧は燃焼期間を通じてほぼ一定 であり, 主流の流量はほぼ一定と推察される。他方で主燃料 の流量は時間とともに変動している .これは配管長に起因 する非定常な効果であると思われる．本報においては自発 


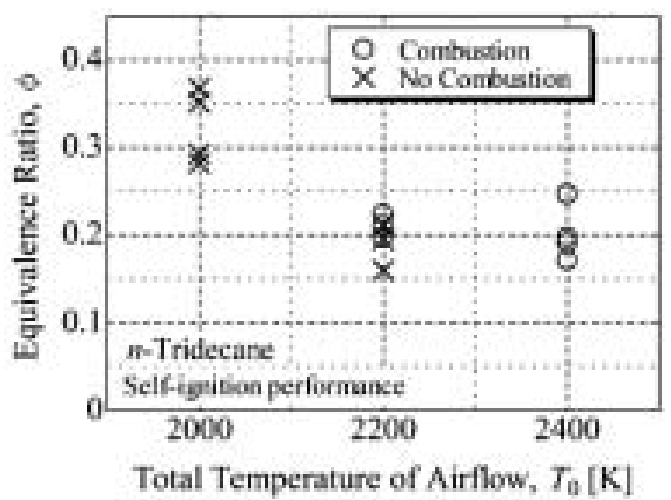

第 6 図 正トリデカンの自発点火特性

点火や保炎の可否を決める限界当量比という観点から，得 られた燃料流量の最大值を使って，光の試験の当量比を評 価することとする. 噴射期間の当量比の平均值は弚の最大 值の $85 \%$ から $92 \%$ 程度の範囲にあり，本報で述べる当量比 は $-12 \%$ 程度の誤差を含んでいるといえる .

3.2 自発点火試験 自発点火試験においては, 主流総温 と液体燃料を押すガスの背圧を変化させて実験を行ってお り, 主流総温は $2000 \mathrm{~K}$ から $2400 \mathrm{~K}$ の間て変化させた . 本 報においては自発点火の可否は, 第 4 図に示されたような 壁面の圧力上昇から判断している. 火炎の樣子や点火の過 程については本報では議論可能なデータがないが，過去 ${ }^{8)}$ に同樣の燃焼器で主燃料をケロシンとして自発点火の樣子 を高速度カメラ (4000fps) を用いて観察しており, 弚れと 同樣な現象が生じているものと推測している .ケロシンの 自発点火の観察においては, キャビティより下流で自発点 火 (発光の確認) 後, $2 \mathrm{~ms}$ から $3 \mathrm{~ms}$ の間に火炎が上流に 遡り，キャビティからキャビティ下流にかけて火炎が空間 的に安定し保炎している樣子か観察されている.

第 6 図は正トリデカンを燃料とした場合の, 自発点火の 可否を主流総温と燃料当量比のグラフ上に示したものであ る. 各プロットが 1 回の通風試験を示しており，図中にお ける○印が自発点火した場合, × 印が自発点火しなかった 場合を示している.この図に示されるように試験した当量 比の範囲内においては, 総温が $2000 \mathrm{~K}$ では自発点火が起 こらず, 他方総温が $2400 \mathrm{~K}$ においてはすべてのケースで 自発点火している.総温 $2200 \mathrm{~K}$ においては当量比 0.2 付近 において, 自発点火するケースと自発点火しないケース双 方が起こっており，これは主に当量比の計測誤差によるも のと推測している.一般に当量比の増加に伴って自発点火 しやすくなると予測されることから，第 6 图より当量比が 0.3 の場合には， $2400 \mathrm{~K}$ および $2200 \mathrm{~K}$ で自発点火が起こ り，2000Kでは自発点火が起こらないと推測される．もち ろん過剩な発熱により不始動となり，主流が亜音速となる 可能性もあるが，ここでは燃料間の自発点火特性の比較を 行うためにこのような指標を用いることとする. 第 7 図は このような考えに基づいて, 当量比が 0.33 の場合に予測さ れる自発点火の可否について, アルカン炭素数を横軸, 主 流総温を縦軸としてまとめたものである .この図からアル

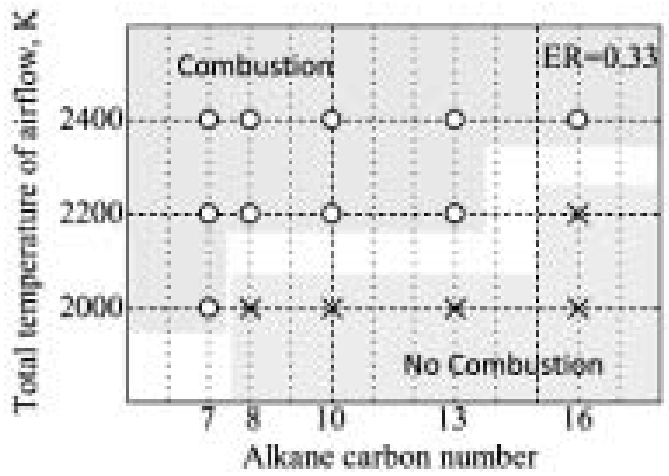

第 7 図 アルカン炭素数および気流総温が自発点火特性に及ぼす影響

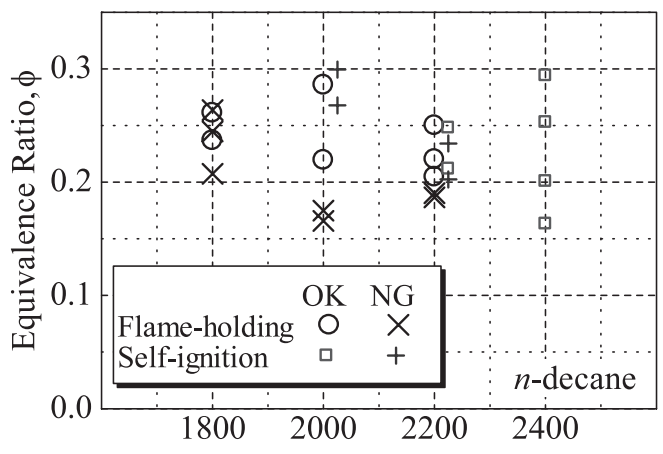

Total temperature of airflow, $T_{0}, \mathrm{~K}$

第 8 図 正デカンの保炎特性

カン炭素数が小いほど, 気流総温が高いほど自発点火し やすいことがわかる.アルカン炭素数が小さいことは揮発 性がよいことに関連しており，本実験結果は揮発性のよい 燃料ほど自発点火特性がよいことを示している。

3.3 保炎試験 主に自発点火実験で着火しなかった気流 総温および当量比を対象にして, パイロット水素を用いて 点火後に, パイロット水素の供給か断たれても保炎可能か どうかの試験を行った . 第 8 図に正デカンの保炎実験の結 果を示す. 図中のプロットは第 6 図と同樣に , 各プロットが 1 回の通風試験を示しており, 図中には自発点火試験の結 果も合わせて示している.この図に示されるように自発点 火試験においては着火が確認されなかった気流総温，およ び当量比についても保炎か確認された .このような保炎特 性の評価として, 各々の気流総温において保炎可能であつ た最小の当量比と保炎不可能であった最大の当量比を用い ることとする . 各気流総温における保炎可能な限界の当量 比は, 第 8 図中における保炎可能であった最小の当量比よ り小さく，保炎不可能であった最大の当量比より大きい値 であると予測される．しかしながら，現象の不確かさや当 量比の計測誤差のために，第 8 図の $1800 \mathrm{~K}$ に見られるよ うに常に保炎可能であった最小の当量比の方が，保炎不可 能であった最大の当量比より大きい値とは限らない，逆に 言えば，保炎可能であった最小の当量比の方が保炎不可能 であった最大の当量比より大きい場合には，この 2 つの当 量比の間に保炎可能な限界当量比が存在し, 再現性のある 


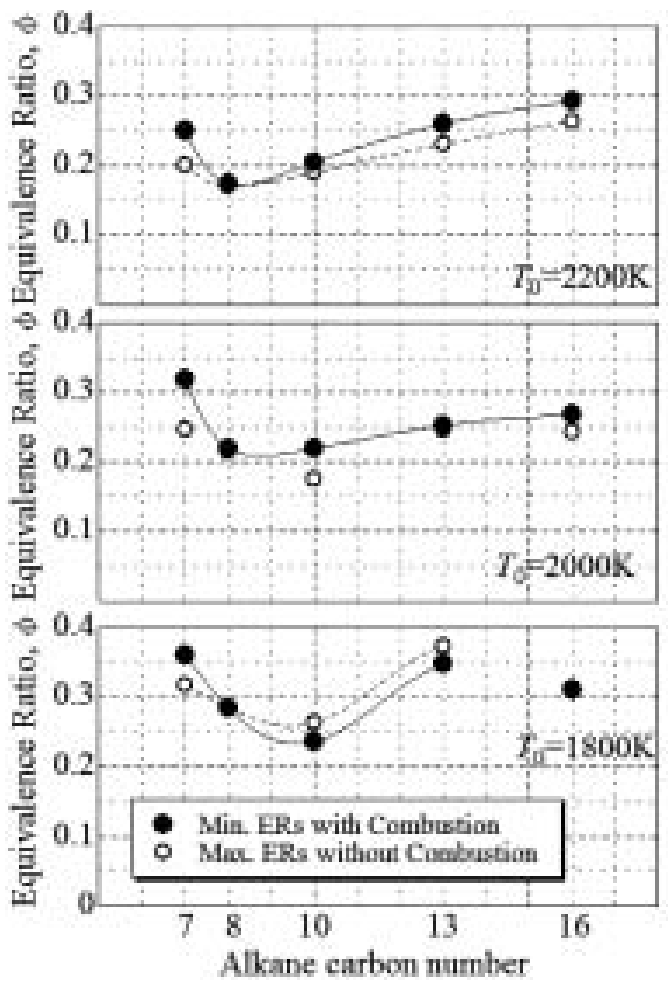

第 9 図 アルカン炭素数と保炎特性の関係

現象であると考えることができる .この 2 つの当量比をア ルカン炭素数の関数として示したものが第 9 図である . 図 においてプロットが塗りつぶされたものが保炎した最小の 当量比, 中が塗りつぶされていないものが保炎しなかった 最大の当量比を示している.この図に示されるように気流 総温が $2200 \mathrm{~K}$ および $2000 \mathrm{~K}$ においては , すべての燃料に おいて (保炎可能な最小の当量比) > (保炎不可能な最大の 当量比) となっており, 保炎可否の限界当量比はこの間に 存在すると予測される.他方で気流総温が $1800 \mathrm{~K}$ の場合 には，(保炎可能な最小の当量比) < (保炎不可能な最大の 当量比) となる場合があり, 現象の再現性が悪いことが示 唆される.第 9 図において, 総温にかかわらずアルカン炭 素数が大きいところでは, アルカン炭素数の上昇に伴って 保炎可能な最小当量比は増加しており，二れは自発点火実 験で得られた傾向と同樣である. 他方で, アルカン炭素数 が小さいところでは, 保炎可能な最小当量比がアルカン炭 素数に対して減少しており，これから化学反応特性につい ても考慮する必要があることが示唆される．

3.4 考察 自発点火や保炎可能な限界当量比が燃料に よって異なることについて考察を行う. 燃焼器内の自発点 火や保炎については, 燃料の燃烓器内の滞留時間 $\tau_{\text {res }}$ と混 合気が自発点火に至るまでの化学的誘導時間 $\tau_{\text {chem }}$ を用い て議論されることが多い, 10). 本報においては, 燃料の滞留 時間の間に燃料が蒸発する時間を考えなければならず，こ れを物理的な誘導時間 $\tau_{\text {phys }}$ として定義する．すなわち，燃 焼器内において自発点火や保炎するかどうかの判定は，

$$
\tau_{\text {res }}>\tau_{\text {chem }}+\tau_{\text {phys }}
$$

が成立すれば，自発点火・燃焼するものと理解できる．この ような燃料液滴の自発点火の考察において誘導時間を物理 的側面と化学的側面に分離することは必ずしも正しくない が，考察を容易にするため分離して議論を行う . 式 (1) に おける右辺を総誘導時間と以下では述べることとする．し かしながら後述のように, 現象の定性的な理解を助けるも のであったが必ずしも定量的な一致は見られなかった .

まず混合気の滞留時間 $\tau_{\text {res }}$ であるが , 燃焼器の長さ $L_{\text {c.c. }}$. を気流の速度 $U_{\infty}$ で除したものを代表時間と考える．

$$
\tau_{\text {res }}=L_{\text {c.c. }} / U_{\infty}
$$

$L_{\text {c.c. }}$ については自発点火・保炎試験ともに燃焼器長さ $400 \mathrm{~mm}$ としてここでは考察する .これはケロシンの燃焼 試験 ${ }^{8)}$ において，保炎している場合でも火炎はキャビティ より下流にまで広がっていることによる．この見積もりを 用いると，滞留時間は $0.3 \mathrm{~ms}$ 程度となる．過去 ${ }^{11)}$ に同樣 の燃焼器で, ケロシン, GTL 軽油, 正トリデカンの噴霧の 樣子を比べたが，光れらの樣子はおよ等しく，流れ場は 燃料種に大きくは依存しないと予想されるので，ここでは 滞留時間は気流条件が決まれば燃料によらず一定であると 考える.

次に物理的な誘導時間 $\tau_{\text {phys }}$ であるが，液滴が気流から 一樣な熱流束で加熱され沸点に達するまでの時間として以 下のように仮定する .

$$
\tau_{\mathrm{phys}}=\frac{\rho_{1} V c\left(T_{\mathrm{bp}}-T_{10}\right)}{h S\left(T_{\text {gas }}-T_{\mathrm{bp}}\right)}
$$

ここで, $T_{\mathrm{gas}}, T_{\mathrm{bp}}, T_{10}$ は各々，気流の温度，液相の沸点， 液相初期温度であり，光の他の記号は以下のとおりである $\rho_{\mathrm{l}}$ : 液相密度 $\left[\mathrm{kg} / \mathrm{m}^{3}\right], c$ : 液相比熱 $[\mathrm{J} / \mathrm{kgK}], h$ : 熱伝達係 数 $\left[\mathrm{W} / \mathrm{Km}^{2}\right], S:$ 代表面積 $\left[\mathrm{m}^{2}\right], V$ : 代表体積 $\left[\mathrm{m}^{3}\right]$.

液相の密度など各物性値の算出にあたっては文献 12)を 参考に $\left(T_{\mathrm{bp}}+T_{10}\right) / 2$ の温度における值を求め，また熱伝 達に関してはヌッセルト数を 2.0 と仮定する .ここで夜滴 の直径であるが, これは微粒化特性に依存し, 燃料種, 当 量比などに依存する.しかしながら，乥れらに対する知見 は十分ではないため，ここでは燃料種や当量比，気流全温 などによって液滴径の分散が変化しないと仮定して考察す る . 代表液滴径であるが，静止雰囲気中にて本報と同樣な 噴射機構を用いて正デカンの燃料粒径の測定を前方微小角 散乱粒径計測法 (LDSA) により行ったところ，ザウター 平均粒径 (SMD) が $4.9 \mu \mathrm{m}$ であり, 最大粒径は $15 \mu \mathrm{m}$ か ら $20 \mu \mathrm{m}$ の間であった .この計測装置においては粒径の測 定下限界が $5 \mu \mathrm{m}$ 程度であることから，ここでは代表粒径

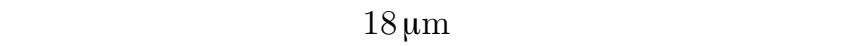
なわちすべての噴射された燃料が気体になる時刻が , 物理 的誘導時間に対応することとなる．

化学的誘導時間 $\tau_{\text {chem }}$ についてであるが , ここでは Horning ら ${ }^{13)}$ が提案している混合気の点火遅れに関する実験式 を用いる. Horning らは, プロパン, 正ブタン, 正へプタ ン, 正デカンについて 1300〜 $1700 \mathrm{~K}, 1$ ～ $4 \mathrm{~atm}$ の条件で 


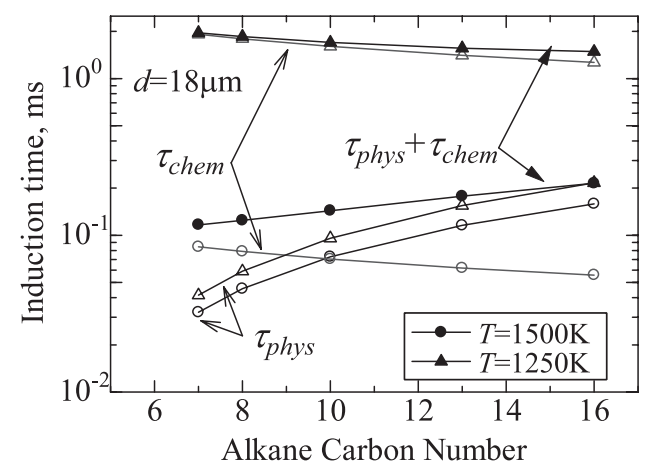

(a) $\tau_{\text {phys }} \gg \tau_{\text {chem }}$ または $\tau_{\text {phys }} \ll \tau_{\text {chem }}$ となる場合

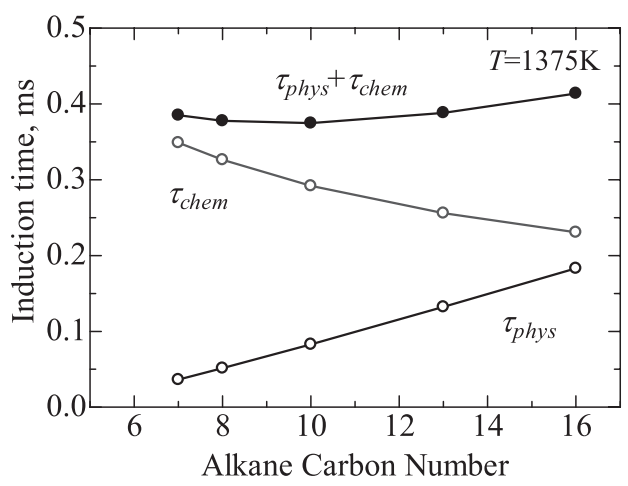

(b) $\tau_{\text {phys }} \sim \tau_{\text {chem }}$ となる場合

第 10 図＼cjkstart誘導時間に及ぼす温度の影響

衝撃波管を用いた実験を行い，量論混合比の点火遅れにつ いて以下の実験式を示している .

$$
\begin{aligned}
\tau_{\text {chem }}= & 9.4 \times 10^{-12} P^{-0.55} X_{\mathrm{O}_{2}}^{-0.63} C^{-0.50} \\
& \times \exp (46,550 / R T) .
\end{aligned}
$$

点火遅れ時間 $\tau_{\text {chem }}$ は $\mathrm{s}$, 雾囲気圧力 $P$ は $\mathrm{atm}$, 活性化工 ネルギは $\mathrm{cal} / \mathrm{mol}$ の単位で表示してある.$X_{\mathrm{O}_{2}}$ は酸素の モル分率, $C$ はアルカン炭素数である.算出にあたっては マッハ 2 の主流の条件，すなわち非燃焼時の静圧，静温を 用いて算出した .

第 10 図は異なる温度における $\tau_{\text {phys }}, \tau_{\text {chem }}$ および $\tau_{\text {phys }}+$ $\tau_{\text {chem }}$ についてアルカン炭素数を横軸として示したもので ある.アルカン炭素数の増加に伴い, 物理的誘導時間 $\tau_{\mathrm{phys}}$ は増加し化学的誘導時間 $\tau_{\text {chem }}$ は減少するが, 兴の温度依 存性は化学的誘導時間の方が大きい. 第 10 図 (a)の見積も りでは静温 $1500 \mathrm{~K}$ において，物理的誘導時間が支配的で アルカン炭素数に対して総誘導時間 $\tau_{\text {phys }}+\tau_{\text {chem }}$ は増加 する．他方て静温 $1250 \mathrm{~K}$ においては，化学的誘導時間の 方が支配的であり総誘導時間は炭素数の増加とともに減少 している.自発点火試験で得られた現象は，このうち温度 が高い領域の現象か観察されたものと思われる . 気流の総 温を下げた場合には，滞留時間 $\tau_{\mathrm{res}}$ に対して総誘導時間が 長くなり自発点火に至らなかったものと考えられる.第 10 図 (b)においては, これら物理的誘導時間と化学的誘導時 間が拮抗しており, 光の結果, 総誘導時間がアルカン炭素 数 8〜10のあたりで極小值を取っていることがわかる .こ
のような総誘導時間の極小値は第 9 图における限界当量比 の極小値に対応しているといえる .

以上の考察は蒸発と化学反応の誘導時間のみから実験結 果を定性的には説明するものであるが，微粒化特性につい ては考慮しておらず，燃料種が微粒化特性に与える影響に ついては今後検討が必要である. また考察にて示されたよ うに, 温度変化による化学的誘導時間の变化が大きく, 定 量的に議論するには特に燃料が経験する温度を丁寧に見積 もる必要がある . 化学的誘導時間の見積もりであるが, 一 般に点火遅れの実験式を導く実験結果は, 各研究者によっ て実験装置や点火遅れの定義などが多少異なり，特に異な る燃料における結果を単純比較して実験式を導くのは困難 である．本報で検討しているような比較的高温低圧におけ る実験結果は限られている上, 異なる燃料における結果を 同一の実験式にまとめるような試みは極めて少なく，これ が定量的な検討を困難にしている一因でもある .これらの 点が今後の検討課題である.

\section{4. ま と め}

スクラムジェットェンジンの模擬燃焼器を用いて単成分 の正アルカン液体燃料の燃焼特性について実験的に調べた . キャリアガスを用いた燃料噴射による自発点火試験と，パ イロット水素を燃焼の初期に用いた保炎試験を行った . 正 アルカンはアルカン炭素数が大きくなるほど, 揮発性は劣 るが化学反応性は向上するとされるので, 弚の拮抗する効 果について誘導時間の観点から考察を行った .

燃料の自発点火試験においては, 気流全温が高いほど，ま たアルカン炭素数が小さいほど自発点火特性が良好であっ た、これから自発点火試験を行った試験条件では，蒸発な どの物理的な過程が支配的なものと推測された . 他方 , 保 炎試験においては, アルカン炭素数が 8 10 あたりで相対 的に小さい当量比で保炎することか確認された . 考察から 保炎試験においては，揮発性などの物理的特性と化学反応 性が拮抗している状況であると定性的に理解された 。

本研究の実施に当たり，岐阜大学 高橋周平准教授，東京 大学 内海正文技術専門員, 奥抜竹雄技術専門員, 東京大学 大学院生の風見秀樹氏 (当時), 橋本 晋氏 (当時), 東京大 学学部生の平本 歩氏 (当時), 日本大学学部生の長尾康司 氏 (当時) のこ協力を頂いた .ここに記して謝意を表する．

\section{参 考 文 献}

1) 大坂 淳, 瓜生田義貴, 今村 宰, 山下清孝, 高橋周平, 津江光 洋, 河野通方 : スクラムジェットエンジン燃焼器内におけるケロシ ンの燃焼特性 , 日本航空宇宙学会論文集 , 55 (2007), pp. 98-103.

2) Owens, M., Segal, C. and Auslender, A. H.: Effects of Mixing Schemes on Kerosene Combustion in a Supersonic Airstream, J. Propul. Power, 13 (1997), pp. 525-531.

3) Yu, G., Li, J. G., Chang, X. Y., Chen, L. H. and Sung, C. J.: Investigation of Kerosene Combustion Characteristics with Pilot Hydrogen in Model Supersonic Combustor, J. Propul. Power, 17 (2001), pp. 1263-1272.

4) Yu, G., Li, J. G., Chang, X. Y., Chen, L. H. and Sung, C. J.: Fuel Injection and Flame Stabilization in a Liquid-Kerosene- 
Fueled Supersonic Combustor, J. Propul. Power, 19 (2003), pp. 885-893.

5) Fan, X., Yu, G., Li, J. and Zhang, X.: Investigation of Vaporized Kerosene Injection and Combustion in a Supersonic Model Combustor, J. Propul. Power, 22 (2006), pp. 103-110.

6) Mitani, T., Hiraiwa, T., Sato, S., Tomioka, S., Kanda, T. and Tani, K.: Comparison of Scramjet Engine Performance in Mach 6 Vitiated and Storage-Heated Air, J. Propul. Power, 13 (1997), pp. 635-642.

7) Yu, K. H., Wilson, K. J. and Schadow, K. C.: Effect of Flame-Holding Cavities on Supersonic-Combustion Performance, J. Propul. Power, 17 (2001), pp. 1287-1295.

8) Hashimoto, S., Hiramoto, A., Tsue, M., Kono, M., Ishikawa, Y., Suzuki, S. and Ujiie, Y.: A Study of Supersonic Combustion Using Various Liquid Hydrocarbon Fuels, Proceedings of Asian Joint Conference on Propulsion and Power, 2008, B4-1 (in CD-ROM).

9) Niioka, T., Terada, K., Kobayashi, H. and Hasegawa, S.:
Flame Stabilization Characteristics of Strut Divided into Two Parts in Supersonic Airflow, J. Propul. Power, 11 (1995), pp. 112-116.

10) Jeong, E., Jeung, I.-S., Choi, J.-Y., O'Byrne, S. and Houwing, A. F. P.: Analysis and Size Determination of Cavity Flameholder in the Supersonic Combustor, 7th AsiaPacific Conference on Combustion, 2009, 10122 (in CD$\mathrm{ROM})$.

11) Hashimoto, S., Kazami, H., Tsue, M. and Kono, M.: Effects of Liquid Fuel Properties on Supersonic Combustion, 18th International Society for Air Breathing Engine Conference, 2007, ISABE 2007-1174 (in CD-ROM).

12) Poling, B. E., Prausnitz, J. M. and O'Connel, J. P.: The Properties of Gases and Liquids, Fifth ed., McGraw Hill, Singapore, 2007, pp. 4.1-4.52.

13) Horning, D. C., Davidson, D. F. and Hanson, R. K.: Study of the High-Temperature Autoignition of n-Alkane/ $\mathrm{O}_{2} / \mathrm{Ar}$ Mixtures, J. Propul. Power, 18 (2002), pp. 363-371. 